\title{
The occurrence of microdiamonds in Mesoproterozoic Chapada Diamantina intrusive rocks - Bahia / Brazil
}

\author{
GISLAINE A. BATTILANI ${ }^{1,2}$, NEWTON S. GOMES ${ }^{1}$ and WILSON J. GUERRA ${ }^{2}$ \\ ${ }^{1}$ Departamento de Geologia da Escola de Minas, Universidade Federal de Ouro Preto (DEGEO/EM/UFOP) \\ Campus Universitário da UFOP, Morro do Cruzeiro, 35400-000 Ouro Preto, MG, Brasil \\ ${ }^{2}$ Fundação Gorceix, Logradouro 0390, 57, Vila Itacolomy, 35400-000 Ouro Preto, MG, Brasil \\ Manuscript received on March 3, 2005; accepted for publication on September 26, 2006; \\ presented by BENJAMIN B. BRITO NEVES
}

\begin{abstract}
The origin of diamonds from Serra do Espinhaço in Diamantina region (State of Minas Gerais) and in Chapada Diamantina, Lençóis region (State of Bahia) remains uncertain, even taking into account the ample research carried out during the last decades. The lack of typical satellite minerals in both districts makes a kimberlitic source for these diamonds uncertain. In mid 18th century the occurrence of a metamorphosed igneous rock composed of martite, sericite and tourmaline was described in Diamantina region and named hematitic phyllite, considered by some researchers as a possible diamond source. Similar rocks were found in Lençóis and examined petrographically and their heavy mineral concentration was investigated by means of scanning electron microscopy (SEM). Petrographic analyses indicated an igneous origin for these rocks and SEM analyses showed the discovery of microdiamonds. Geochronological studies using the Ar/Ar technique in muscovites yielded minimum ages of $1515 \pm 3 \mathrm{Ma}$, which may correlate with $1710 \pm 12 \mathrm{Ma}$ from $\mathrm{U}-\mathrm{Pb}$ method in igneous zircons from the hematitic phyllites. Both rock types also have the same mineral and chemical composition which leads to the conclusion that the intrusive rocks were protolith of the hematitic phyllites. This first discovery of microdiamonds in intrusive rocks opens the possibility of new investigation models for diamond mineralization in Brazilian Proterozoic terrains.
\end{abstract}

Key words: microdiamonds, intrusive rocks, Tombador Formation, Serra do Espinhaço, Mesoproterozoic, Chapada Diamantina.

\section{INTRODUCTION}

The origin of the presence of diamonds in Proterozoic sedimentary rocks along the Serra do Espinhaço in Minas Gerais and Bahia States has been controversial since their discovery in the 1790's and the pioneer papers from Spix and Martius (1828) and Eschwege (1833). None of the several suggestions to explain the origin of the gem proved to be conclusive.

Some authors (Pflug 1965, Chaves 1998, Chaves et al. 1993, 2000, 2001) proposed that diamonds found in Mesoproterozoic conglomerates originated from an

Correspondence to: Gislaine Amorés Battilani

E-mail: gislaine@nupetro.com.br; gislaine@degeo.ufop.br unknown, eroded or buried distal kimberlitic source located in the São Francisco Craton.

Other researchers suggested a proximal source located within the confines of the diamondiferous Proterozoic sedimentary basin. Two possibilities have been proposed to explain this proximal source. One states that diamonds bearing kimberlites and lamproites were eroded or buried by thick sedimentary sequences (Almeida-Abreu and Munhóz 1983, Fleischer 1995, 1998). It is almost impossible to prove the first hypothesis because until now kimberlites and lamproites have not been identified. The other possibility indicates as a probable diamond source, a rock mainly composed of mus- 
covite and martite, which occurs in the Diamantina district in Minas Gerais State and is named hematitic phyllite (Walls 1919, Guimarães 1930, Correns 1932, Moraes and Guimarães 1930, 1931, Moraes 1934, Barbosa 1951, G. Herrgesell, unpublished data, Almeida-Abreu 1996, Almeida Abreu and Renger 1999, 2001). The second hypothesis seems more likely to be confirmed, because a possible diamond source can be easily found in the diamond district of Diamantina, in Minas Gerais and is usually associated with the main mining activities of the area.

In 1984, Herrgesell (G. Herrgessell, unpublished data) for the first time described rocks similar to the hematitic phyllite of Minas Gerais in Chapada Diamantina in Bahia. The main difference between the Minas Gerais hematitic phyllites and the rocks found in Bahia is the metamorphic grade. In Chapada Diamantina, Bahia, the igneous rocks are intruded in sedimentary rocks of the Proterozoic Tombador Formation. Crystallinity studies carried out by Battilani et al. (2000) in illites from these sedimentary rocks revealed that the maximum temperature reached the anchimetamorphic facies, whereas in the Diamantina region of Minas Gerais the metamorphic grade corresponds to the upper greenschist facies.

In order to obtain more information on these enigmatic intrusive rocks and their potential as the primary sources of diamonds, field, mineralogical, heavy mineral, geochronological and geochemical works were carried out in samples of intrusive rocks from Chapada Diamantina in Bahia.

\section{THE STUDY AREA}

The study area is located in the central part of Bahia State, between the geographic coordinates $12^{\circ} 00^{\prime} /$ $13^{\circ} 00^{\prime} \mathrm{S}$ and $42^{\circ} 00^{\prime} / 41^{\circ} 00^{\prime} \mathrm{W}$. It encompasses a small part of Chapada Diamantina (Fig. 1), and is crossed by the highway that links Salvador to Brasília (BR 242). The main rivers present in the area are the Paraguaçú, Santo Antônio and São José, whose beds have been exploited for diamonds.

\section{REGIONAL GEOLOGY}

The Espinhaço Supergroup is $c a$. $1200 \mathrm{~km}$ long, cropping out from the Quadrilátero Ferrífero in Minas Gerais to the boundary of Piauí-Pernambuco States.

In Bahia State, the Espinhaço Supergroup is divided into Espinhaço Setentrional and Chapada Diamantina, respectively west and east of the Paramirim River. In the Chapada Diamantina area, the Espinhaço Supergroup is divided, from base to top, into Rio dos Remédios, Paraguaçú and Chapada Diamantina groups (Inda and Barbosa 1978). The schematic representation of the stratigraphic sequence of the Espinhaço Supergroup in Chapada Diamantina was proposed by Rocha (1993) as illustrated on Figure 2. The Chapada Diamantina Group, according to Guimarães and Pedreira (1990), is composed of continental (Tombador and Morro do Chapéu formations) and marine (Caboclo Formation) sequences. The Tombador Formation composed of sandstones, conglomerates and pelites is the basal unit of the Chapada Diamantina Group. The outcropping area exceeds $20,000 \mathrm{~km}^{2}$ and at least two of its conglomeratic levels are known to be diamond-bearing.

According to Torquato and Fogaça (1981) the metamorphic grade in Chapada Diamantina increases from north to south and does not exceed the greenschist facies, confirmed by Varajão and Gomes (1998) and Battilani et al. (2000), on the basis of crystallinity studies of illite from the Tombador Formation sediments.

In addition to the sedimentary sequences, dikes and sills of volcanic rocks named muscovite-martite fels (G.A. Battilani et al., unpublished data) and diabase dikes occur associated with basal sediments of the Tombador Formation. Volcaniclastic rocks crop out in the Morro do Pai Inácio, intercalated within Tombador Formation siliciclastic sequences (Battilani et al. 1998).

The Tombador Formation was affected by hydrothermal events that caused intense tourmalinization. Tourmalinite veins that crosscut the sedimentary rocks are up to $30 \mathrm{~cm}$ thick and are composed of quartz and tourmaline and subordinate muscovite, rutile, barite and zircon. This hydrothermal event also caused intense alteration and tourmalinization of the rocks that compose the dikes and sills.

\section{MATERIALS AND METHODS}

Detailed sampling of sills and dikes, totaling 150 samples for petrographic studies and chemical analyses, was carried out in 90 days of fieldwork. Approximately $600 \mathrm{~kg}$ 


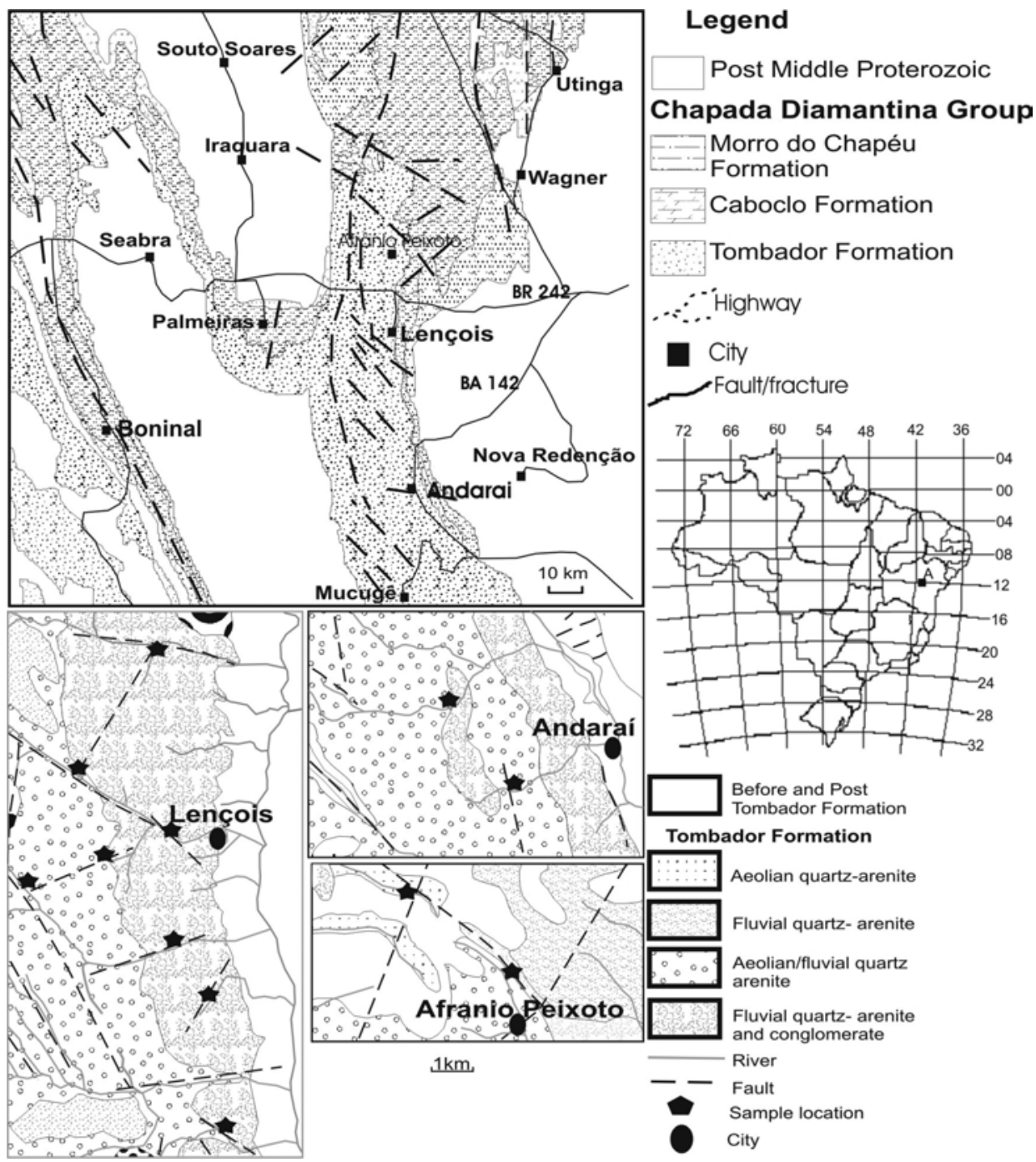

Fig. 1 - Regional geologic map of the Espinhaço Range and the Chapada Diamantina area showing the location of the studied outcrops (modified from Barbosa and Dominguez 1996). Detailed geologic map with the location of the samples analyzed in this study (modified from Bonfim and Pedreira 1990 and Guimarães and Pedreira 1990).

of fresh igneous rocks were collected from nine outcrops (Fig. 1) for separation of heavy minerals.

The samples were ground in a ball mill and sieved. Fine material under 400\# was discarded. Seven fractions $(35,48,65,100,150,200,270 \#)$ resulted from this first stage of sample preparation and the heavy minerals were concentrated in a KNELSON Concentrator, model KCMD3, series MD39907504903197, which belongs to the Gorceix Foundation.

After concentration, the material was leached with hot $1 \mathrm{M} \mathrm{HCl}$ for Fe removal and then dried. Panning and dense liquids (Bromoform, D = 2.85 and 2-iodine methane, $\mathrm{D}=3.325$ at $99 \%$ ) were used in the second stage of mineral separation. In the last stage, the heavy minerals were handpicked under the microscope.

Whenever identification of heavy minerals was not possible under optical microscope or the stereomicroscope, EDS analyses were carried out in the microanalysis laboratory of the Geology Department of the Ouro Preto Federal University, equipped with a JEOL-JSM - 


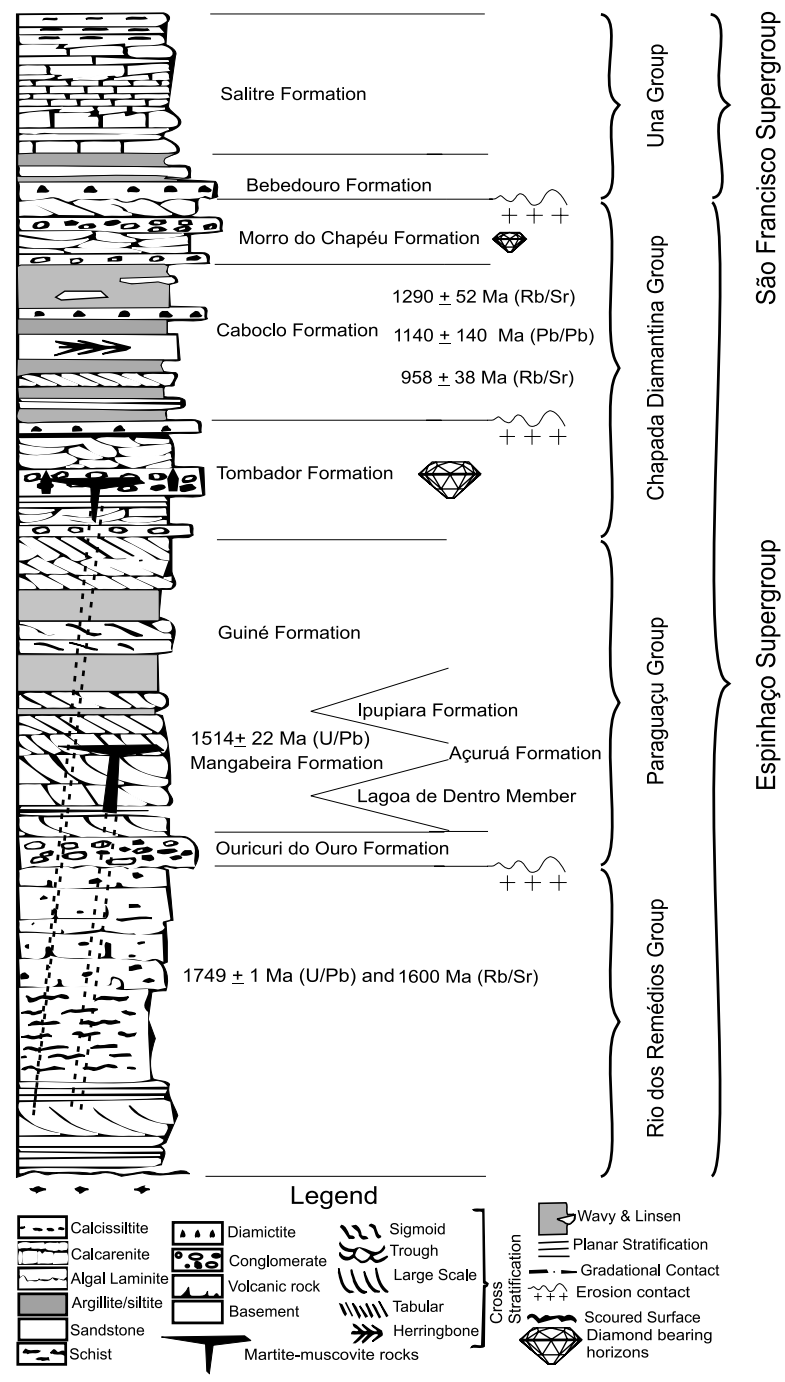

Fig. 2 - Schematic representation of the stratigraphic sequence of the Espinhaço and São Francisco Supergroups in the Chapada Diamantina, Bahia area (modified from Rocha 1993).

5510 with a EDS Thermo-NORAN detector. Minerals were fixed to a sample holder and covered with a thin layer of carbon. The operation conditions were an acceleration voltage of $20 \mathrm{kv}$ and a current of $6 \mathrm{~mA}$.

\section{RESULTS}

\section{THE INTRUSIVE Rocks}

The intrusive rocks or muscovite-martite fels are dense $\left(2.9 \mathrm{~g} / \mathrm{cm}^{3}\right)$, fine grained, grey and slightly red when altered. In the field, the thickness varies from 0.8 to $30 \mathrm{~m}$ (Fig. 3). The NNW-SSE-striking dikes and sills cross-

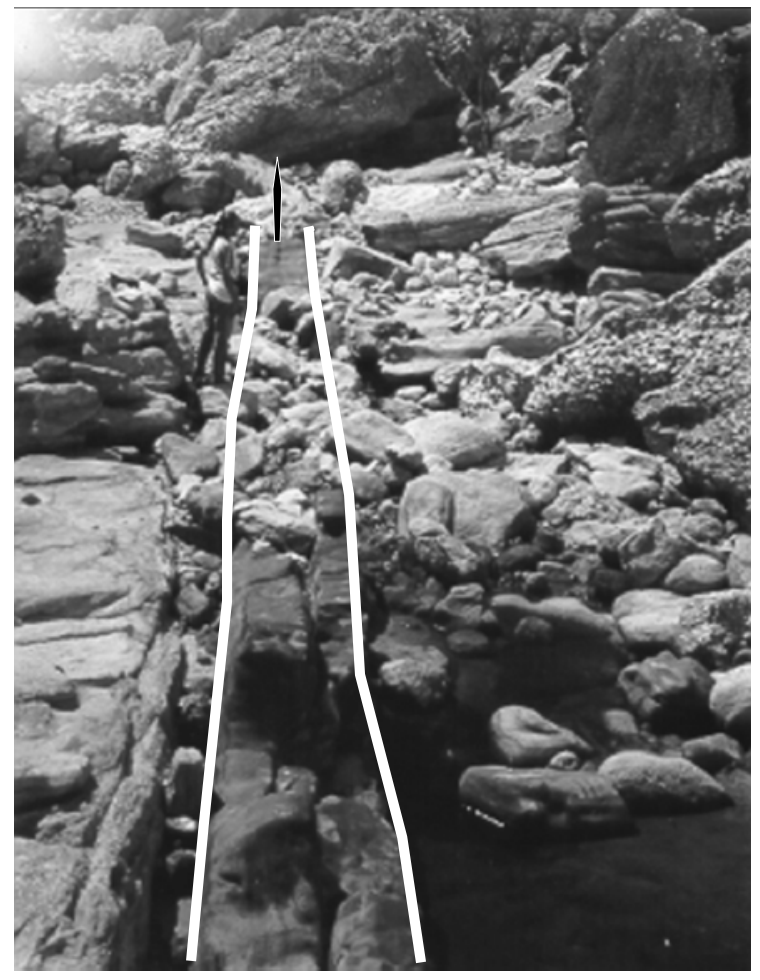

Fig. 3 - Outcrop of dike cross-cutting sandstones of Tombador Formation. The field relationships show clearly the dike has igneous origin.

cut or are intercalated with the diamond-free sedimentary sequences.

${ }^{40} \mathrm{Ar} /{ }^{39} \mathrm{Ar}$ analyses of metasomatic muscovite by Battilani et al. (2005) from the Chapada Diamantina region yielded an age of $1515 \pm 3 \mathrm{Ma}$ interpreted as the minimum age of intrusion. By means of the $\mathrm{U}-\mathrm{Pb}$ method in igneous zircon, T.M. Dussim (1994, unpublished data) dated the hematitic phyllites of Diamantina (Minas Gerais), obtaining an age of $1710 \pm 12 \mathrm{Ma}$.

Both on outcrops and under the microscope, spherical structures similar to amygdales were observed. These are filled with muscovite or a mixture of muscovite and tourmaline.

The primary minerals are totally altered and the rock is now composed of sericite (45 to $75 \%$ ), martite ( 21.5 to $44.5 \%$ ), and tourmaline (4 to $17.5 \%$ ). Alkaline feldspar laths were pseudomorphosed to tourmaline. Accessory minerals are zircon, gorceixite, baddeleyite, kyanite, pyrite, quartz and chlorite. Well-preserved igneous textures, such as fluidal and trachytic, can be recognized in some samples. 
Despite an exhaustive search, using petrographic and SEM investigations, only one remnant feldspathoid could be identified from the analyzed samples. EDS analyses of the small crystals within the muscovite aggregates showed the presence of $\mathrm{O}, \mathrm{Na}, \mathrm{Al}, \mathrm{Si}, \mathrm{S}, \mathrm{Cl}, \mathrm{K}$, $\mathrm{Ca}$, which allowed the identification of the feldspathoid remains of the sodalite/lausurite isomorphic series. According to Tröger (1969) all of the sodalite series members alter to sericite under hydrothermal conditions.

Tabular phenocrystals, up to $0.5 \mathrm{~mm}$ long, of supposedly former feldspar or feldspathoid were pseudomorphically replaced by fine muscovite aggregates. Muscovite occurs in the following forms:

1) concentrations of small tabular shaped crystals oriented according to the preferential-flow direction;

2) randomly distributed crystals, associated or not with tourmaline;

3) euhedral crystals surrounded by iron oxide minerals or rutile; and

4) filling pseudo-amygdales, associated or not with tourmaline.

Martite occurs as pseudomorphic hematite aggregates crystals after igneous magnetite. The pseudomorphic crystals with an average size of $0.3 \mathrm{~mm}$, are octahedrical, in part intensely fractured and corroded and associated with muscovite and quartz. The rims of several crystals were altered to limonite. Besides typical octahedral forms, the SEM/EDS analyses showed a close association of martite with rutile, which concentrates at the rims or along cleavage planes of the primary crystals. Rutile was probably generated by hydrothermal alteration of Ti-magnetite.

Tourmaline crystals vary from 0.05 to $0.10 \mathrm{~mm}$ in size, are euhedral to subhedral, sometimes zoned, and intergrown with each one. In general, tourmaline is closely associated with muscovite, as well as with opaque minerals or disseminated in the thin section. The largest concentration of tourmaline is found along the weakness directions of the rock as veinlets that can be identified in outcrops. Microprobe analyses showed that the tourmaline composition falls in the schorl-dravite series.

Quartz is probably of secondary origin and occurs as small crystals associated with martite, disseminated together with muscovite, or as veinlets that crosscut the rocks. The rims of the quartz crystals are generally corroded. They are mostly monocrystalline and exhibit straight extinction.

On-going geochemical studies have revealed that the muscovite-martite fels has an alkaline composition typical of intraplate tectonic environments. The following tables show results of geochemical analyses of the intrusive rocks from Chapada Diamantina-BA as well as four samplesizes of the hematitic phyllite from Diamantina-MG. The data were plotted (Figure 4) and is possible to see the similar behavior between the geochemical results from Chapada Diamantina samples and Diamantina samples.

\section{Heavy Minerals}

The study of heavy minerals of igneous rocks showed the presence of zircon, baddeleyite, $\mathrm{Ti}$ and Fe oxides, tourmaline, magnetite, pyrite and two kinds of colorless minerals with adamantine luster, imbricated, or showing quadratic etching figures, as well as negative and positive trigons and grooves (Fig. 5). The colorless crystals were selected with a binocular microscope, eliminating the grains with oxide inclusions or with iron coatings. The clear grains without inclusions were selected for the EDS analyses. Lack of impurities was confirmed by EDS observation. EDS analyses revealed that most of the grains are composed solely of $\mathrm{SiO}_{2}$. EBSD analyses allowed the identification of a preserved coesite nucleus in the samples.

EDS analyses showed that five colorless mineral grains from $80 \mu \mathrm{m}$ to $200 \mu \mathrm{m}$ in size, are composed of pure carbon (Fig. 5) and were interpreted as microdiamonds. Detailed EDS analyses in fragments of the fresh intrusive rock also revealed the presence of an euhedral mineral with cubic habit, composed solely of carbon (Fig. 6), which was also interpreted as diamond.

\section{DISCUSSION}

Field data clearly indicate an igneous intrusive origin of the so called "muscovite-martite fels" (Battilani et al. 2005) because they form subvertical dikes intruding subhorizontal sandstones layers. The sandstones do not display any evidence of metamorphism or deformation as supported by illite crystallinity determinations 

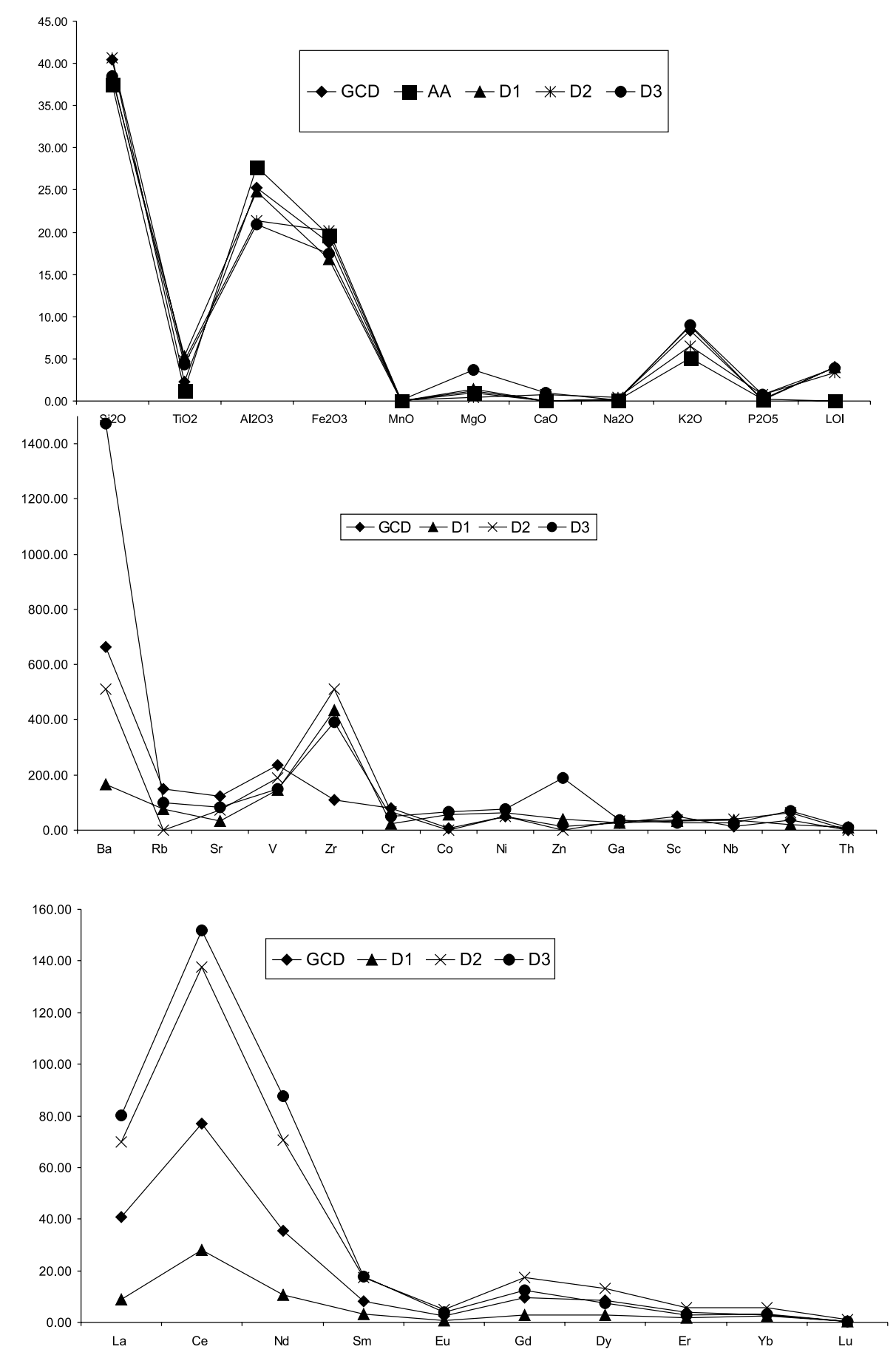

Fig. 4 - A plot of geochemical analyses showed in Table I. The sample GCD is the average for all samples from Chapada Diamantina - BA. Major elements (wt \%), trace and REE elements (in ppm). Observe that the elements behavior of the Chapada Diamantina samples is similar to the elements behavior of the hematitic philite from Diamantina - MG. 
TABLE I

Table of geochemical analyses of martite-muscovite dikes and sill samples from Chapada Diamantina-BA. Major elements (wt \%) were analyzed by ICP-OES, trace and REE elements (in ppm) by ICP-MS at Act Labs in Canada. For comparison are included chemical analyses of hematitic philite from Diamantina - MG.

The samples AA - (after Almeida-Abreu et al. 2005) and D1, D2 and D3 (after T.M.Dussin, unpublished data). The sample GCD is the average for all samples from Chapada Diamantina - BA. $x$ - not analyzed; n.d. - not detected.

\begin{tabular}{|c|c|c|c|c|c|c|c|c|c|c|c|c|c|}
\hline Sample & $\mathrm{Si}_{2} \mathrm{O}$ & $\mathrm{TiO}_{2}$ & $\mathrm{Al}_{2} \mathrm{O}_{3}$ & $\mathrm{Fe}_{2} \mathrm{O}_{3}$ & $\mathrm{MnO}$ & $\mathrm{MgO}$ & $\mathrm{CaO}$ & $\mathrm{Na}_{2} \mathrm{O}$ & $\mathrm{K}_{2} \mathrm{O}$ & $\mathrm{P}_{2} \mathrm{O}_{5}$ & LOI & $\mathrm{Ba}$ & $\mathrm{Rb}$ \\
\hline GB127 & 38.04 & 2.52 & 28.78 & 17.53 & 0.01 & 0.2 & 0 & 0.21 & 8.9 & 0.18 & 3.99 & 646.23 & 155.04 \\
\hline GB87 & 38.26 & 2.27 & 26.21 & 19.3 & 0.01 & 1.09 & 0 & 0.14 & 8.98 & 0.61 & 4.01 & 665.49 & 135.31 \\
\hline GB99 & 40.72 & 2.66 & 28.79 & 16.53 & 0.01 & 0.6 & 0 & 0.24 & 8.97 & 0.19 & 4.23 & 660.68 & 140.9 \\
\hline GB110 & 43.16 & 2.21 & 23.49 & 15.94 & 0.01 & 2.32 & 0.02 & 0.09 & 9.67 & 0.1 & 4.01 & 671.51 & 231.75 \\
\hline GB152 & 39.12 & 1.91 & 24.93 & 21.28 & 0.01 & 1.17 & 0 & 0.09 & 8.57 & 0.24 & 4.19 & 1522.47 & 177.25 \\
\hline GB155 & 36.85 & 1.73 & 21.83 & 29.13 & 0.01 & 1.42 & 0.27 & 0.11 & 7.98 & 0.11 & 3.75 & 609.33 & 176.09 \\
\hline G17B & 41.73 & 1.76 & 20.29 & 21.56 & 0 & 2.14 & 0.02 & 0.08 & 8.21 & 0.05 & 3.52 & 564 & 172 \\
\hline G50B & 46.45 & 2.59 & 14.05 & 26.9 & 0.02 & 1.71 & 0.16 & 0.06 & 3.59 & 0.23 & 3.05 & 128 & 70 \\
\hline G23A & 38.04 & 2.07 & 25.79 & 19.83 & 0 & 1.16 & 0.02 & 0.1 & 8.86 & 0.22 & 4.1 & 895 & 135 \\
\hline G23B & 37.76 & 2.24 & 26.79 & 19.14 & 0 & 1.05 & 0.02 & 0.14 & 8.53 & 0.21 & 4.27 & 1302 & 126 \\
\hline G76 & 46.2 & 1.84 & 21.45 & 16.52 & 0 & 2.63 & 0 & 0.31 & 7.84 & 0.029 & 3.37 & 218 & 164 \\
\hline G88 & 39 & 2.41 & 31.09 & 13.36 & 0 & 0.2 & 0 & 0.27 & 9.16 & 0.05 & 4.18 & 483 & 143 \\
\hline G89 & 39.1 & 2.44 & 31.53 & 13.33 & 0 & 0.17 & 0.1 & 0.42 & 8.41 & 0.68 & 4.78 & 618 & 146 \\
\hline G96A & 41.62 & 2.49 & 28.14 & 12.31 & 0 & 0.7 & 0 & 0.16 & 9.08 & 0.03 & 4.39 & 320 & 128 \\
\hline GCD & 40.43 & 2.22 & 25.23 & 18.76 & 0.01 & 1.18 & 0.04 & 0.17 & 8.34 & 0.21 & 3.99 & 664.55 & 150.02 \\
\hline AA & 37.51 & 1.3 & 27.71 & 19.63 & 0 & 1 & 0 & 0.1 & 5.1 & 0.169 & 0 & 0 & 0 \\
\hline D1 & 38.28 & 5.29 & 24.83 & 16.78 & 0 & 1.41 & 0 & 0.19 & 8.91 & 0.1 & 4.04 & 166 & 77.3 \\
\hline D2 & 40.7 & 4.8 & 21.4 & 20.2 & 0.06 & 0.43 & 0.8 & 0.45 & 6.5 & 0.72 & 3.37 & 510 & 0 \\
\hline D3 & 38.5 & 4.33 & 20.92 & 17.43 & 0.07 & 3.65 & 0.96 & 0.08 & 9 & 0.79 & 3.92 & 1472 & 99.4 \\
\hline
\end{tabular}

\begin{tabular}{c|r|r|r|r|r|r|r|r|r|r|r|r|r}
\hline Sample & \multicolumn{1}{c|}{$\mathrm{Sr}$} & \multicolumn{1}{c|}{$\mathrm{V}$} & \multicolumn{1}{c|}{$\mathrm{Zr}$} & \multicolumn{1}{c|}{$\mathrm{Cr}$} & \multicolumn{1}{c|}{$\mathrm{Co}$} & \multicolumn{1}{c|}{$\mathrm{Ni}$} & \multicolumn{1}{c}{$\mathrm{Zn}$} & \multicolumn{1}{c|}{$\mathrm{Ga}$} & \multicolumn{1}{c}{$\mathrm{Sc}$} & \multicolumn{1}{c}{$\mathrm{Nb}$} & \multicolumn{1}{c}{$\mathrm{Y}$} & \multicolumn{1}{c}{$\mathrm{Th}$} & $\mathrm{Cs}$ \\
\hline GB127 & 158.3 & 129.29 & 125.47 & 49.42 & 0.89 & 14.95 & 7.22 & 28.04 & 54.18 & 13.24 & 25.76 & 1.5 & 1.33 \\
\hline GB87 & 105.02 & 234.01 & 114.97 & 48.29 & 5.26 & 68.48 & 12.41 & 26.51 & 58.07 & 11.95 & 92.33 & 1.39 & 4.38 \\
\hline GB99 & 159.27 & 180.26 & 125.66 & 104.9 & 2.76 & 26.04 & 15.39 & 25.88 & 45.42 & 13.51 & 45.42 & 1.58 & 3.47 \\
\hline GB110 & 14.61 & 230.57 & 111.62 & 70.61 & 8.83 & 78.42 & 11.82 & 31.03 & 54 & 11.68 & 21.48 & 1.52 & 3.57 \\
\hline GB152 & 141.62 & 232.48 & 93.6 & 92.49 & 3.49 & 32.98 & 11.21 & 27.36 & 54.42 & 9.91 & 21.76 & 1.04 & 1.72 \\
\hline GB155 & 28.06 & 220.41 & 85.48 & 131.83 & 3.16 & 39.85 & 7.8 & 25.14 & 47.41 & 9 & 10.52 & 0.96 & 2.08 \\
\hline G17B & 35 & 250 & 89 & 161 & 9.5 & 43 & 18 & 25 & 43 & 10 & 20 & 1.4 & 4 \\
\hline G50B & 24 & 536 & 174 & 59 & 16 & 108 & 25 & 26 & 40 & 14 & 60 & 2.3 & 1.4 \\
\hline G23A & 220 & 249 & 101 & 63 & 5.5 & 93 & 12 & 29 & 56 & 11 & 25 & 1.8 & 4.9 \\
\hline G23B & 279 & 229 & 105 & 55 & 6.2 & 51 & 10 & 27 & 55 & 12 & 47 & 1.8 & 4.5 \\
\hline G76 & 131 & 208 & 85 & 96 & 15 & 61 & 24 & 26 & 46 & 10 & 16 & 1.3 & 4.5 \\
\hline G88 & 31 & 179 & 109 & 42 & 1.1 & 22 & 0 & 28 & 53 & 13 & 36 & 1.7 & 1.5 \\
\hline G89 & 381 & 208 & 113 & 74 & 0.9 & 10 & 17 & 31 & 64 & 13 & 84 & 1.8 & 1.5 \\
\hline G96A & 25 & 202 & 114 & 64 & 2.6 & 30 & 0 & 22 & 48 & 14 & 18 & 1.8 & 3.4 \\
\hline GCD & 123.78 & 234.86 & 110.49 & 79.40 & 5.80 & 48.48 & 12.28 & 27.00 & 51.32 & 11.88 & 37.38 & 1.56 & 3.02 \\
\hline AA & 0 & 0 & 0 & 0 & 0 & 0 & 0 & 0 & 0 & 0 & 0 & 0 & 0 \\
\hline D1 & 32.5 & 147 & 436 & 23 & 57.1 & 62 & 41.3 & 27.9 & 33.5 & 37.3 & 19.3 & 8.71 & 0 \\
\hline D2 & 74 & 188 & 510 & 68 & 0 & 50 & 0 & 32 & 38 & 38.7 & 64 & 0 & 0 \\
\hline D3 & 82.5 & 148 & 391 & 48.9 & 65.7 & 76 & 189 & 36.5 & 26.5 & 26.5 & 70.8 & 10 & 0 \\
\hline
\end{tabular}


TABLE I (continuation)

\begin{tabular}{|c|c|c|c|c|c|c|c|c|c|c|c|c|}
\hline Sample & $\mathrm{Ta}$ & Hf & $\mathrm{La}$ & $\mathrm{Ce}$ & $\mathrm{Nd}$ & $\mathrm{Sm}$ & $\mathrm{Eu}$ & $\mathrm{Gd}$ & Dy & $\mathrm{Er}$ & $\mathrm{Yb}$ & $\mathrm{Lu}$ \\
\hline GB127 & 0.91 & 3.56 & 73.19 & 134.21 & 50.25 & 11.63 & 3.29 & 10.11 & 6.79 & 2.66 & 1.72 & 0.24 \\
\hline GB87 & 0.84 & 3.36 & 14.21 & 32.07 & 21.2 & 7.03 & 2.74 & 13.46 & 16.05 & 9.43 & 7.88 & 1.12 \\
\hline GB99 & 0.92 & 3.71 & 36.59 & 65.11 & 57.04 & 16.02 & 6.38 & 19.65 & 14.08 & 4.61 & 3.04 & 0.41 \\
\hline GB110 & 0.79 & 3.24 & 244.26 & 435.85 & 136.52 & 19.1 & 4.77 & 11.63 & 5.12 & 2.47 & 2.55 & 0.4 \\
\hline GB152 & 0.66 & 2.65 & 17.34 & 43.51 & 37.46 & 9.73 & 2.72 & 10.08 & 7.49 & 2.46 & 1.57 & 0.22 \\
\hline GB155 & 0.6 & 2.44 & 4.48 & 9.99 & 6.88 & 2.31 & 0.85 & 2.99 & 2.48 & 1.15 & 1.03 & 0.15 \\
\hline G17B & 0.67 & 2.6 & 10 & 22 & 13 & 3.7 & 1.3 & 4.9 & 4.8 & 2.5 & 2.4 & 0.35 \\
\hline G50B & 0.82 & 4.8 & 7.8 & 25 & 21 & 9.5 & 2.13 & 15 & 12 & 5.3 & 4.2 & 0.62 \\
\hline G23A & 0.79 & 2.9 & 88 & 155 & 58 & 11 & 2.73 & 9.9 & 9.2 & 2.9 & 1.9 & 0.26 \\
\hline G23B & 0.83 & 3.1 & 34 & 63 & 35 & 9.2 & 3 & 14 & 15 & 5.2 & 2.8 & 0.35 \\
\hline G76 & 0.64 & 2.5 & 5.4 & 12 & 8.1 & 2.4 & 0.84 & 3 & 3.3 & 1.8 & 1.9 & 0.27 \\
\hline G88 & 0.92 & 3.3 & 6.8 & 20 & 13 & 3.5 & 1.27 & 4.7 & 6 & 3.6 & 3.3 & 0.49 \\
\hline G89 & 0.88 & 3.3 & 18 & 38 & 27 & 8 & 2.83 & 11 & 13 & 7.8 & 6.1 & 0.9 \\
\hline G96A & 0.9 & 3.5 & 9.8 & 22 & 10 & 3.2 & 1.1 & 4.1 & 3.7 & 1.7 & 1.6 & 0.25 \\
\hline GCD & 0.80 & 3.21 & 40.71 & 76.98 & 35.32 & 8.31 & 2.57 & 9.61 & 8.50 & 3.83 & 3.00 & 0.43 \\
\hline $\mathrm{AA}$ & 0 & 0 & 0 & 0 & 0 & 0 & 0 & 0 & 0 & 0 & 0 & 0 \\
\hline D1 & 0 & 0 & 9.04 & 27.94 & 10.72 & 3.21 & 0.84 & 2.81 & 3 & 1.93 & 2.45 & 0.39 \\
\hline D2 & 0 & 0 & 69.74 & 137.7 & 70.77 & 17.54 & 4.87 & 17.47 & 13.01 & 5.73 & 5.58 & 0.89 \\
\hline D3 & 0 & 0 & 80.15 & 152 & 87.46 & 17.69 & 4.04 & 12.25 & 7.45 & 2.98 & 3.11 & 0.52 \\
\hline
\end{tabular}

in these rocks, that estimated temperature conditions between high diagenesis to anchimetamorphism. Although the studied intrusive rocks are of Proterozoic age they do not show any evidence of deformation or metamorphism.

The mineral composition of the muscovite-martite fels is incompatible with that of an igneous rock. According to Trögger (1969), hematite does not form at temperatures higher than $600^{\circ} \mathrm{C}$ in magmatic rocks, occurring as a product of magnetite autometasomatism under deuteric conditions and is, therefore, named martite and muscovite is totally unstable at temperatures higher than $750^{\circ} \mathrm{C}$.

According to Deer et al. (1992), magnetite is one of the most abundant oxides in igneous rocks and usually occurs as an accessory mineral and only occasionally at higher concentrations. Magnetite in several igneous rocks, and particularly in mafic rock types, may be enriched in $\mathrm{Ti}$, thus being named titanomagnetite. It is suggested that the martite in the studied rocks is a result of transformation of magnetite, titanomagnetite or both, which is confirmed by the octahedral shape of the crystals and by the presence of rutile along the rims and cleavage planes of martite crystals. Muscovite is clearly a product of alteration or transformation of feldspar or feldspathoid.

The presence of tourmaline (up to $17 \%$ ) is another important factor to confirm the transformation of the primary minerals in the studied rocks. Tourmaline found in the studied intrusive rock samples occurs mainly filling microfractures, indicating a hydrothermal origin. The similarity of the chemical composition of the muscovite-martite fels from Bahia and of the hematitic phyllites from Minas Gerais corroborates the supposition that the muscovite-martite fels from Bahia, comprise a non-metamorphic equivalent (protolith) of the hematitic phyllites like those that occur in Minas Gerais, and that both are hydrothermally altered igneous source rocks of the diamonds.

Geochronological studies by Battilani et al. (2005) and Dussim (T.M. Dussim, unpublished data), respectively on muscovite-martite fels and hematitic phyllites, 

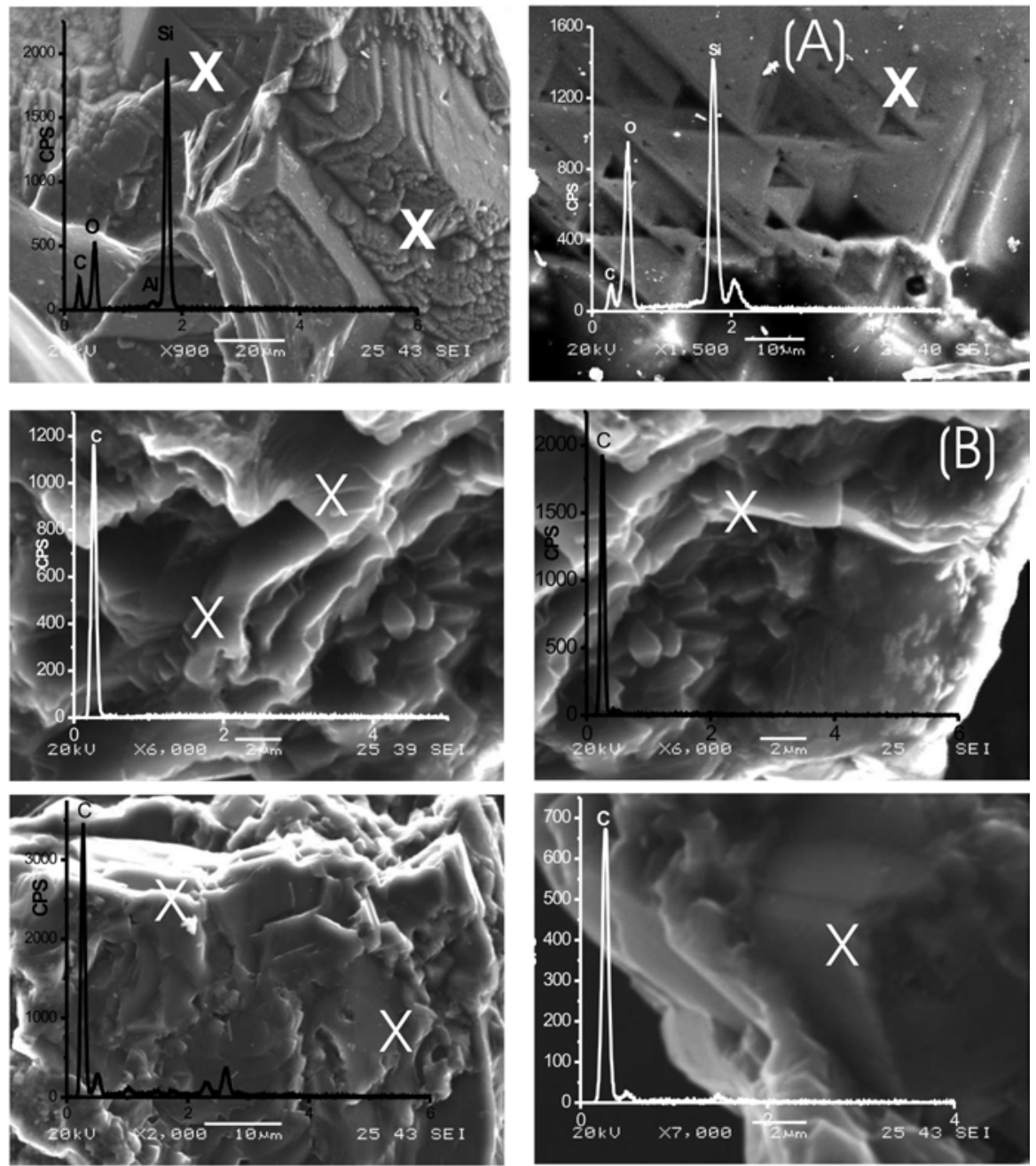

Fig. 5 - (A) SEM images and EDS spectrum of grains composed exclusively of $\mathrm{SiO}_{2}$ with dissolution structures. (a) corrosion structures and negative trygons; (b) negative trygons. The trygons were originated by dissolution. $\mathrm{X}=$ analized points. (B) SEM images and EDS spectrum of grains composed exclusively of carbon identified in heavy mineral concentrates from the intrusive rocks. $\mathrm{X}=$ analized points.

corroborate this interpretation.

Trögger (1969) points out that the reaction

$$
{ }^{2} \mathrm{CO}+\mathrm{CH}_{4}={ }^{3} \mathrm{C}+{ }^{2} \mathrm{H}_{2} \mathrm{O}
$$

necessary for graphite formation occurs only under pegmatitic conditions. Another possibility could be the assimilation of organic carbon by the magma. Besides, the high density of the crystal aggregates and their physical properties (habit, color, luster) lead to the conclusion that the crystals identified are in fact microdiamonds. However, it is possible that these microdiamonds are fragments of larger diamonds or carbonados, generated during the intense grinding stage of sample preparation. Diamond, despite its high degree of hardness, is easily fragmented.

The features observed in minerals composed solely of $\mathrm{SiO}_{2}$ and $\mathrm{C}$ were also identified in diamond microcrystals that form carbonados and in "quartz inclusions" in these carbonados (G.A. Battilani et al., unpublished data). Another on-going study concerns the grains composed exclusively of $\mathrm{SiO}_{2}$. Their density is higher than 3.3, which rules out quartz, which has a density of 2.65. 


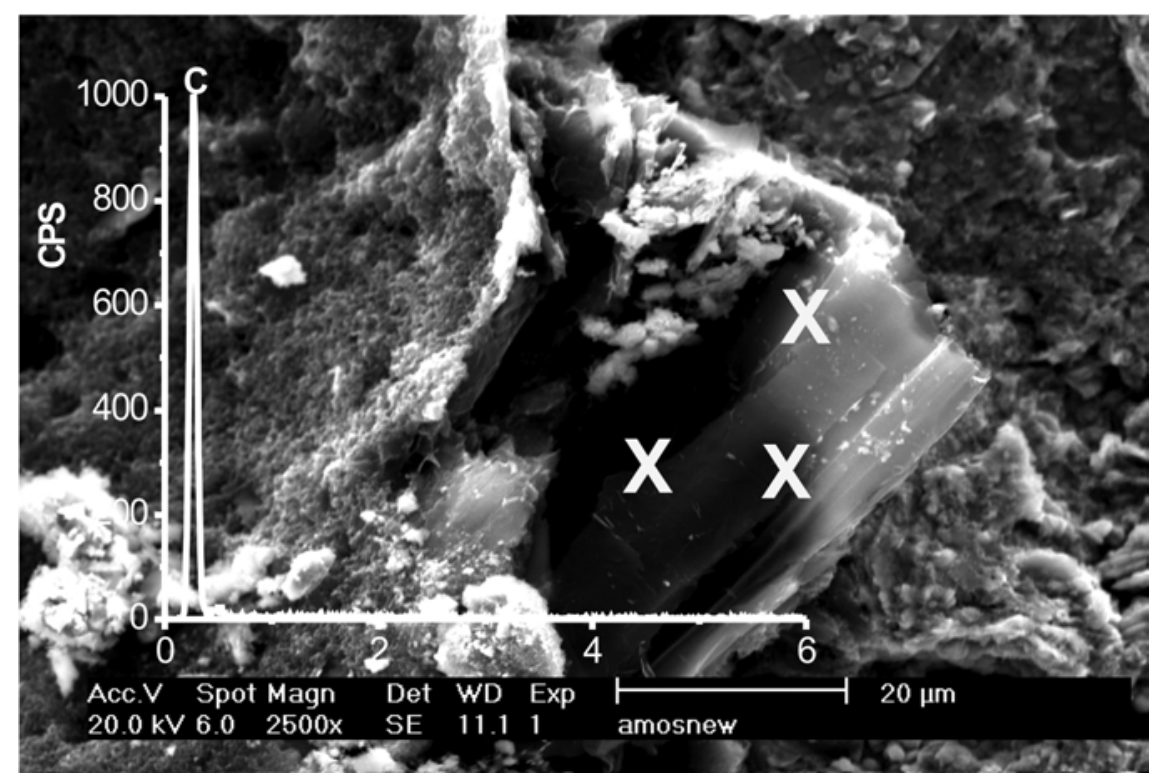

Fig. 6 - SEM image and EDS spectrum of a carbon mineral, showing cubic habits identified as diamond from a hand sample of intrusive rock. This mineral is associated with the same minerals identified in thin sections of rocks containing martite and muscovite. $\mathrm{X}=$ analized points.

Coesite, a quartz polymorph, is dense and typical of rocks that underwent high-pressure conditions. According to Souza (M.M. Souza, unpublished data), coesite has been described in association with diamond-rich deposits in Venezuela. Iwanuch et al. (2005) describe the occurrence of coesite associated with diamond in kimberlite pipes of Juína, Mato Grosso State, Brazil. EBDS analyses showed preserved core of coesite in ten colorless grains that were analyzed in this study.

Fieldwork showed unconformities in the Tombador Formation, expressed by erosive contacts on top of some sills. Erosion and reworking of these microdiamondbearing intrusive rocks can constitute a mechanism of diamond concentration in the Lençóis, Bahia conglomerates. These diamond-rich conglomerates are younger and were not crosscut by intrusive rocks.

\section{CONCLUSIONS}

Dikes and sills of muscovite-martite fels were observed restricted at the lower and barren levels of the Tombador Formation, never underlying course clastic diamondbearing levels.

Textural analyses and chemical composition of these dikes and sills in the Tombador Formation, indi- cate an igneous origin. The mineralogical composition although, is supposed to be the result of the action of hydrothermal solutions, also responsible for the high concentration of tourmaline, which reaches $17.6 \%$.

The mineral composition of the intrusive rocks of Chapada Diamantina is identical to the hematitic phyllites of Minas Gerais, suggesting that these phyllites could be a product of regional greenschist metamorphism of similar hydrothermally altered igneous rocks. Geochronological data obtained with the Ar/Ar technique applied to secondary metasomatic muscovites from the intrusive rocks could be correlated with $\mathrm{U}-\mathrm{Pb}$ data yielded by igneous zircons from the hematitic phyllites.

The presence of upper erosive contacts in intrusive sills suggests evidence of unconformities in Tombador Formation. Erosion and reworking of the intrusive rocks could represent a source of diamonds on the Tombador Formation upper levels.

Micro diamonds would represent pulverized fractions of larger diamonds, carbonados, or both, generated during the mechanical treatment of samples. This occurrence of microdiamonds in the intrusive rocks shades light on new investigation models for diamond mineralizations in Brazilian Proterozoic terrains. 


\section{ACKNOWLEDGMENTS}

The authors thank Coordenação de Aperfeiçoamento de Pessoal de Nível Superior (CAPES) for a Ph.D. scholarship, Conselho Nacional de Desenvolvimento Científico e Tecnológico (CNPq) also for a Ph.D. scholarship, sandwich program (process number 200636/01-4) and Gorceix Foundation, for financial support to this work.

\section{RESUMO}

A origem dos diamantes da Serra do Espinhaço na região de Diamantina, Minas Gerais e na Chapada Diamantina, na região de Lençóis, Bahia, permanece incerta apesar das inúmeras pesquisas desenvolvidas, ao longo das últimas décadas. A ausência de minerais satélites típicos em ambos os distritos, torna incerta a possibilidade de fonte kimberlítica para os diamantes. Na região de Diamantina registra-se, desde meados do século XVIII, a ocorrência de uma rocha metamórfica, composta por martita, sericita e turmalina, denominada filito hematítico e considerada por alguns pesquisadores como uma provável fonte dos diamantes. Rochas similares foram encontradas na região de Lençóis e submetidas a estudos petrográficos tendo a concentração de minerais pesados sido investigada por microscopia eletrônica de varredura (MEV). As análises petrográficas permitiram determinar uma origem ígnea para as rochas e as análises de MEV mostraram a ocorrência de microdiamantes. Estudos geocronológicos com a técnica $\mathrm{Ar} / \mathrm{Ar}$ em muscovitas revelaram idades de $1515 \pm 3$ m.a. que são correlacionáveis às idades de $1710 \pm 12$ m.a., obtidas pelo método $\mathrm{U}-\mathrm{Pb}$, em zircões dos filitos hematíticos. Ambos litotipos apresentam composições química e mineralógica idênticas o que permite concluir que os filitos hematíticos tiveram como protólito as rochas intrusivas. Essa descoberta inédita de microdiamantes nas rochas intrusivas descortina a possibilidade de adoção de novos modelos prospectivos para mineralizações de diamantes em terrenos do Proterozóico brasileiro.

Palavras-chave: microdiamantes, rochas intrusivas, Formação Tombador, Serra do Espinhaço, Mesoproterozóico, Chapada Diamantina.

\section{REFERENCES}

Almeida-Abreu PA. 1996. O Caminho das Pedras. Geonomos 4: 77-93.

AlmeidA-Abreu PA AND Munhóz DTV. 1983. A reconstituição paleogeográfica e o estudo dos minerais pe- sados como indicativos de áreas fontes primárias dos diamantes da Serra do Espinhaço, Minas Gerais. In: SIMPósio de Geologia de Minas Gerais, 2, Belo Horizonte, MG, Brasil, SBG Núcleo, p. 219-234.

AlmeidA-Abreu PA And Renger F. 1999. Sobre a polêmica da origem do diamante na Serra do Espinhaço (Minas Gerais): um enfoque mineralógico - de Mario Luiz de Sá Carneiro Chaves, Joachim Karfunkel and Darci Pedro Svisero. Rev Bras Geocienc 29: 669-674.

Almeida-Abreu PA And Renger F. 2001. Origem dos diamantes da Serra do Espinhaço Meridional: O exemplo do distrito diamantífero de Sopa-Guinda (Diamantina MG). Rev Bras Geocienc 31: 511-520.

Almeida-Abreu PA, Renger F, Abreu FR and Silva RR. 2005. Field trip to the diamond district of SopaGuinda (Diamantina, MG/Brazil). In: AlMEIDA-ABREU PA AND Abreu FR (Eds), Simpósio Brasileiro de Geologia do Diamante, 4 (South American Symposium on diamond Geology, Bol. 14, Diamantina, MG. Brazil. SBG Núcleo, 289-200.

BARBOSA JSF AND Dominguez JML. 1996. Geologia da Bahia: texto explicativo para o mapa geológico ao milionésimo. Salvador, BA, Brasil, SGM 400 p.

BARBOSA O. 1951. Contribuição à origem do diamante em Diamantina, Estado de Minas Gerais, DNPM - Divisão de Geologia e Mineração, Rio de Janeiro, RJ, Brasil, 36 p.

BAtTILANi GA, Gomes NS AND GUerRa WJ. 1998. Ocorrência de Rochas vulcanoclásticas Formação Tombador, Grupo Chapada Diamantina, na região do Morro do Pai Inácio, Bahia. Congresso Brasileiro de Geologia, 40. Belo Horizonte, MG, Brasil, SBG, 528 p.

Battilani GA, VARAJÃo AFD AND Gomes NS. 2000. Metamorphic degree variations in Proterozoic sandstones of the Tombador Formation, Bahia State, Brazil. Zbl Geol Paläont 1: 917-926.

Battilani GA, Vasconcelos PM, Gomes NS AND GUERRA WJ. 2005. Geochronological data of dykes and sills intruding Proterozoic Sequences of the Tombador Formation, Bahia - Brazil. In: SIMPÓsIO DO CRÁTON Do SÃo Francisco, 3, Salvador, BA, Brazil, SBG Núcleo NE, p. 139-142.

Bonfim LFC And Pedreira AJCL. 1990. Programa de Levantamentos Geológicos Básicos do Brasil - PLGB. Folha Lençóis, SD.24-V-A-V. Escala 1:100.000. Brasília, DF, Brasil DNPM: CPRM-SUREG/SA, 130 p.

Chaves ML. 1998. Sobre a polêmica da origem do diamante na Serra do Espinhaço (Minas Gerais): Um enfoque mineralógico. Rev Bras Geocienc 28: 285-294. 
Chaves ML, Dupont H, KARfunkel J And SVisero DP. 1993. Depósitos diamantíferos de Minas Gerais: uma revisão. In: Simpósio DE GeOlogia do Diamante, 1, Cuiabá, MT, Brasil, SBG Núcleo de MT, p. 79-100.

Chaves ML, Dussin TM and Sano Y. 2000. The source of the Espinhaço Diamonds: Evidence form Shrimp U-Pb zircon ages of the Sopa Conglomerate and $\mathrm{Pb}-\mathrm{Pb}$ zircon evaporation ages of metavolcanic rocks. Rev Bras Geocienc 30: 265-269.

Chaves ML, Karfunkel J And Hoover DB. 2001. Diamonds from the Espinhaço Range (Minas Gerais, Brazil) and their redistribution through the geologic record. J South Am Earth Sci 14: 277-289.

Correns CW. 1932. Die Diamanten des Hochlandes von Minas Geraes, Brasilien. Zeits Prakt Geol 40 (Heft I): $161-176$

Deer WA, Howie RA And Zussman J. 1992. An Introduction to the Rock-Forming Minerals. $2^{\text {nd }}$ ed., Hong Kong, Longman Scientific \& Technical, 696 p.

EsCHWEGE WL. 1833. Pluto Brasiliensis. Berlin, 634 p.

FLEISCHER R. 1995. Prospecção e economia do diamante da Serra do Espinhaço. Geonomos 3: 27-30.

FLEISCHER R. 1998. A rift model for the sedimentary diamond deposits of Brazil. Miner Depos 33: 238-254.

Guimarães D. 1930. Gênese do Diamante. An Acad Bras Cienc 2: 75-86.

Guimarães JT And Pedreira AJ. 1990. Programa de Levantamentos Geológicos Básicos do Brasil - PLGB. Folha Utinga, SD.24-V-A-II. Escala 1:100.000. Brasília, DF. Brasil, DNPM. CPRM-SUREG/SA, 142 p.

INDA HAV AND BARBOSA JSF. 1978. Texto Explicativo para o Mapa Geológico do Estado da Bahia, Escala 1:1.000.000. Salvador, BA, Brasil, SME/CPM. 137 p.

Iwanuch W, Makeev AB and Kondo MM. 2005. Películas metálicas sobre os diamantes de Juína, Mato Grosso. In: Simpósio de Geologia do Diamante, 4, Diamantina, MG, Brasil, SBG Núcleo de MG, p. 73-75.
Moraes LJ. 1934. Depósitos diamantíferos no norte do Estado de Minas Gerais. DNPM/SFPM, Rio de Janeiro, RJ, Brasil, (Bol 03), 45 p.

Moraes LJ And Guimarães D. 1930. Geologia da Região diamantífera do norte de Minas Gerais. An Acad Bras Cienc 30(II): 153-186.

Moraes LJ And Guimarães D. 1931. The DiamondBearing region of northern Minas Gerais Brazil. Geol and Miner Surv, p. 502-530.

Pflug R. 1965. A geologia da parte meridional da Serra do Espinhaço e zonas adjacentes, MG, Brasil, DNPM Divisão de Geologia e Mineração, 55 p.

Rocha AJD. 1993. Morro do Chapéu Folha SC.24-Y-C-V; Estado da Bahia. Texto Explicativo e mapas. Brasília, DF, Brasil, CPRM, Programa de Levantamentos Geológicos Básicos do Brasil - PLGB, 170 p.

SPIX JD AND MARTIUS CFP. 1828. Reise in Brasilien 1817-1820. München. Staatsbibliotek Universität München, V 1, 389 p.

TORquato JR AND FogaÇA ACC. 1981. Correlações entre o Supergrupo Espinhaço no Brasil, o Grupo Chela em Angola e as formações Nosib e Khoabendus da Namíbia. In: Simpósio Cratón do SÃo Francisco E SUAS FAIXAS MARGINAIS. Salvador, BA, Brasil, p. 87-98.

TrÖGER WE. 1969. Optische Bestimmung der gesteinsbildenden Minerale. 2. Auflage, Stuttgart: E Schweizerbart'sche Verlagsbuchhandlung, $822 \mathrm{p}$.

VARAJÃo AD AND Gomes NS. 1998. Petrological significance of illitic clays in Proterozoic sandstones of the Tombador Formation, Chapada Diamantina, Brazil. Zbl Geol Paläont 3-6(I): 767-778.

WALLS RS. 1919. The Existence of diamond-bearing "Pipes" in Brazil. Geol Mag LVII, p. 447-449. 